\title{
PERAN SITUS JEJARING SOSIAL DALAM PERSEPSI RESELLER
}

\author{
M. Fatkhur Rozi \\ Fakultas Ekonomi UIN Maulana Malik Ibrahim Malang \\ Jalan Gajayana 50 Malang \\ Email: oyik_1976@yahoo.com
}

\begin{abstract}
The rapid development and growth of social networking sites in Indonesia raises opportunities for sales activity mainly resellers. Sales activity via the social networking site is an outgrowth of an earlier concept that e-marketing. The purpose of this study wanted to gain an understanding of the role of the reseller social networking sites. Methods used in this study is the Focus Group Discussion with 12 people resellers mobile products and clothing as participants. The results of the study explained that social networking sites is an Internet-based tool that serves as a medium of communication for the promotion, negotiation, and transaction. Of exposure obtained explanations focus group discussions that social networking sites are a means of informing bid, bid development, and role as a reseller. The role of social networking sites is as a medium for conveying information, interactions, and transactions.
\end{abstract}

Keywords: social network sites, interactive marketing, focus group discussion, reseller

Internet dan perkembangannya merupakan penemuan penting yang memengaruhi peradaban manusia setelah bahasa. Internet menghilangkan halangan jarak bagi interaksi manusia diberbagai belahan dunia. Seperti halnya interaksi manusia, internet juga memberikan dampak yang cukup besar pada pola dunia bisnis. Salah satu perkembangan yang cukup pesat dari internet ini adalah kemunculan jejaring sosial berupa media-media sosial online.

Rilis National School Boards Association (2012) mengemukakan bahwa di Amerika waktu yang dihabiskan oleh sebagian besar remaja untuk mengunjungi situs jejaring sosial itu hampir sama dengan waktu yang dihabiskan oleh mereka untuk melihat televisi. Masih menurut data yang sama, remaja menghabiskan waktu sekitar sembilan jam selama seminggu untuk mengunjungi dan surfing di situs jejaring sosial. Sebagai contoh perkembangan yang pesat dari jejaring sosial adalah jumlah pengguna twitter hingga tahun 2013 lebih dari 400 juta orang di seluruh dunia (Checktwitter.com, Agustus 2013). Di Indonesia pengguna internet telah mencapai 82 juta orang. Dengan capaian tersebut, Indonesia berada pada peringkat ke-8 di dunia. (Kemkominfo, 2014) Dari jumlah itu, 41 juta di antaranya mengakses lewat smarthphone serta 70 juta diantaranya mengakses sosial media seperti Facebook, Twitter, Path, Instagram.

Bagi dunia pemasaran, internet memberikan dampak komunikasi lebih luas. Menurut Kotler (2003) internet telah meningkatkan kemampuan perusahaan menjalankan bisnis dengan lebih cepat, akurat, mencakup kisaran waktu dan ruang yang lebih luas, dengan biaya yang lebih sedikit, dan dengan kemampuan menyesuaikan tawaran dengan kebutuhan pelanggan dan membuat tawaran menjadi lebih pribadi. Berkait dengan jejaring sosial, pemasar tidak dapat mengabaikan peran social networking websites sebagai media komunikasi pemasaran mereka. Dalam kegiatan pemasaran melalui social networking websites memungkinkan pemasar untuk menerapkan strategi pemasaran interaktif. Dalam kegiatan pemasaran interaktif, konsumen tidak lagi bertindak sebagai peserta pasif yang hanya menerima iklan sebelum melakukan pembelian, melainkan juga ikut proaktif dan interaktif dalam kegiatan pemasaran.

Manuel (2013) menyatakan bahwa internet memiliki beberapa daya tarik dan keunggulan bagi para konsumen. Selain menunjang strategi e-commerce perusahaaan dan layanan perusahaan, internet menciptakan peluang interaksi potensial dengan konsumen 
atau pelanggan pada skala global yang berdampak pada kinerja perusahaan. Sejalan dengan hal tersebut Kautsarina (2013), terkait dengan internet dalam bentuk aplikasi jejaring sosial menyebutkan bahwa tujuan utama UKM menggunakan aplikasi jejaring sosial adalah sebagai sarana memperkenalkan produk kepada daftar pertemanan (pasar). Temuan lain dalam penelitian tersebut menyatakan bahwa pemasaran melalui aplikasi jejaring sosial diketahui oleh sebagian responden dari internet, rekan, dan buku. Aktivitas yang dilakukan adalah dengan mengunggah foto produk, menuliskan status produk, dan menuliskan deskripsi mengenai produk. Disebutkan bahwa terdapat 3 (tiga) dampak jejaring sosial dalam pemasaran UKM yaitu peningkatan jumlah pelanggan, peningkatan penghasilan, dan penghematan biaya promosi.

Analisis lembaga Upright Decision (2012) terkait dengan penggunaan media sosial di Indonesia, terutama aktivitas jual-beli melalui media sosial. Analisis dilakukan berdasarkan data hasil survei terhadap responden yang tinggal di Indonesia. Dari data 344 responden yang diolah, $337 \mathrm{di}$ antaranya menyatakan sebagai pengguna media sosial. Hampir semua responden yang menggunakan media sosial menyatakan mereka menemukan produk yang sesuai dengan keperluan mereka di media sosial. Bahkan hampir sepertiga di antaranya (105 responden) melakukan pembelian melalui media sosial. (www.marketing. co.id)

Perkembangan peran situs jejaring sosial (media sosial) tidak hanya terbatas pada interaksi pertemanan. Dibandingkan dengan bentuk situs web yang lain, jejaring sosial dipandang lebih terhubung dan interaktif oleh masyarakat.

Fungsi utama saluran distribusi adalah menyalurkan barang dari produsen ke konsumen, maka perusahaan dalam melaksanakan dan menentukan saluran distribusi harus melakukan pertimbangan yang baik. Menurut Kotler (2003) distribusi menjalankan fungsi informasi, promosi, negosiasi, pemesanan, pembayaran, kepemilikan, dan berbagi resiko.

Di dunia bisnis online peran distribusi sebagai rantai nilai dimainkan oleh orang yang disebut dengan reseller dan/atau affiliate. Seperti halnya agen, reseller bisa dikatakan sebagai perwakilan penjualan yang memerankan fungsi-fungsi dalam distribusi. Baik agen, reseller, maupun affiliate memeroleh keuntungan dengan memperdagangkan produk orang lain dalam bentuk komisi dalam besaran atau persentase tertentu.
Seiring dengan pertumbuhan pengguna situs jejaring sosial di Indonesia, memunculkan peluang bisnis bagi masyarakat. Banyak di antara anggota masyarakat yang mengambil kesempatan tumbuhnya pengguna situs jejaring sosial untuk menjadi reseller bagi produk tertentu dengan menggunankan situs ini sebagai sarana. Menurut Kotler (2003) kehadiran internet (situs jejaring sosial termasuk di dalamnya) memberikan peluang bagi perusahaan untuk dapat memberikan informasi, melakukan komunikasi, melakukan promosi, dan menjual produk dan jasanya kepada pelanggan dengan lebih cepat dan murah. Pada literatur lain Rayport dan Jaworski (2001) menyatakan bahwa ciri sebuah situs dikatakan efektif apabila memliki kemampuan untuk menciptakan transaksi.

Dari penjelasan di atas permasalahan yang mengemuka adalah bagaimana peran situs jejajring sosial dalam persepsi reseller. Hal ini dilandasi oleh fenomena semakin banyak masyarakat yang mengambil peran sebagai reseller dengan mengandalkan situs jejaring sosial sebagai media (sarana) utama untuk menjalankan bisnis (penjualan). Tujuan penelitian ini adalah mencoba mendapatkan pemahaman reseller tentang peran situs jejaring sosial.

\section{SITUS JEJARING SOSIAL}

Situs jejaring sosial merupakan sebuah web berbasis pelayanan yang memungkinkan penggunanya untuk membuat profil, melihat list pengguna yang tersedia, serta mengundang atau menerima teman untuk bergabung dalam situs tersebut. Tampilan dasar situs jejaring sosial ini menampilkan halaman profil pengguna, yang di dalamnya terdiri dari identitas diri dan foto pengguna (Wikipedia.org, 2012).

Jejaring sosial merupakan salah satu bentuk media sosial yang paling umum digunakan oleh masyarakat di seluruh dunia. Kemampuan jejaring sosial dalam mendukung interaksi sosial dengan teknologi berbasis web mengubah komunikasi menjadi dialog interaktif. Jejaring sosial mengajak siapa saja yang tertarik untuk berpertisipasi dengan memberi kontribusi dan feedback secara terbuka, memberi komentar, serta membagi informasi dalam waktu yang cepat dan tak terbatas.

Saat teknologi internet dan mobile phone makin maju maka jejaring sosial pun ikut tumbuh dengan pesat. Sebagai contoh untuk mengakses facebook atau twitter yang merupakan jejaring sosial, bisa dilakukan dimana saja dan kapan saja hanya dengan 
menggunakan sebuah mobile phone. Demikian cepatnya orang bisa mengakses media sosial mengakibatkan terjadinya fenomena besar terhadap arus informasi tidak hanya di negara-negara maju, tetapi juga di Indonesia. Karena kecepatannya media sosial juga mulai tampak menggantikan peranan media massa konvensional dalam menyebarkan berita-berita.

Pesatnya perkembangan media sosial kini dikarenakan semua orang seperti bisa memiliki media sendiri. Jika untuk memiliki media tradisional seperti televisi, radio, atau koran dibutuhkan modal yang besar dan tenaga kerja yang banyak, maka lain halnya dengan media. Seorang pengguna media sosial bisa mengakses menggunakan sosial media denganjaringan internet bahkan yang aksesnya lambat sekalipun, tanpa biaya besar, tanpa alat mahal dan dilakukan sendiri tanpakaryawan. Media sosial mempunyai ciriciri, yaitu sebagai berikut: pesan yang di sampaikan tidak hanya untuk satu orang saja namun bisa ke berbagai banyak orang contohnya pesan melal ui SMS ataupun internet, pesan yang di sampaikan bebas, tanpa harus melalui suatu gatekeeper, pesan yang di sampaikan cenderung lebih cepat di banding media lainnya dan penerima pesan yang menentukan waktu interaksi.

E-marketing menggambarkan upaya perusahaan untuk memberikan informasi, berkomunikasi, berpromosi, dan menjual produk dan jasanya melalui internet. Jejaring sosial yang merupakan perkembangan internet adalah alat promosi bisnis yang efektif karena dapat diakses oleh siapa saja, sehingga jaringan promosi bisa lebih luas. Media sosial menjadi bagian yang sangat diperlukan oleh pemasaran bagi banyak perusahaan dan merupakan salah satu cara terbaik untuk menjangkau pelanggan dan klien. Media sosial memiliki kelebihan dibandingkan dengan media konvensional, antara lain kesederhanaan, kemampuan membangun hubungan, jangkauan global, dan terukur.

\section{PEMASARAN INTERAKTIF}

Di dalam kegiatan pemasaran interaktif konsumen tidak hanya bertindak sebagai peserta pasif yang menerima iklan sebelum melakukan pembelian, tetapi juga proaktif dan interaktif dalam kegiatan pemasaran. Sukma (2012) menjelaskan bahwa tujuan dari pemasaran interaktif adalah untuk memikat dan memelihara konsumen yang akan menjadi rekan bisnis dalam penciptaan, pembelian, dan pengembangan produk serta layanan. Dan salah satu media yang paling efektif untuk melakukan kegiatan pemasaran interaktif adalah melalui social networking websites.
Proses pemasaran interaktif meliputi 2 metode yaitu, Push Marketing dan Pull Marketing. Pada Pull Marketing, kegiatan pemasaran menyerahkan sepenuhnya kepada konsumen yang membutuhkan informasi, untuk mencari, membaca, atau unduh informasi melalui situs web perusahaan. Pada metode Push Marketing kegiatan pemasaran lebih menggantungkan pada software Web Broadcasters atau Net Broadcasters, seperti Point Cast, BackWeb, dan Castanet (Yuliana, 2000; Sukma; 2012).

Pemasaran interaktif adalah tuntutan menciptakan hubungan yang mendalam dengan pembeli potensial, menggunakan teknologi two-way communication, terutama on-line. Pemasaran interaktif merupakan penggunaan internet untuk mendapatkan one-to-one dialog secara berkelanjutan dengan target audien agar dapat memahami dengan baik. Beberapa keunggulan pemasaran interaktif antara lain: kemampuan akses 24 jam, transaksi real-time, banyaknya informasi yang dapat diberikan, komunikasi langsung dengan konsumen, biaya transaksi yang lebih murah, menjalin hubungan yang langsung dengan konsumen, dan website yang dimiliki dapat menjadi sebuah toko virtual.

\section{PERSEPSI}

Persepsi adalah tindakan menyusun, mengenali, dan menafsirkan informasi sensoris guna memberikan gambaran dan pemahaman tentang lingkungan (Daniel, 2011). Rakhmat (2004) menjelaskan persepsi adalah pengalaman tentang objek, peristiwa, atau hubungan-hubungan yang diperoleh dengan menyimpulkan informasi dan melampirkan pesan. Menurut Engel, et al. (1995) menjelaskan persepsi sebagai proses bagaimana seseorang menyeleksi, mengatur dan menginterpretasikan masukan-masukan informasi untuk menciptakan gambaran keseluruhan yang berarti.

Menurut Vincent (1997) ada beberapa faktor yang memengaruhi terbentuknya persepsi, yaitu: Pengalaman masa lalu, keinginan, dan pengalaman dari teman-teman. Sehingga dapat dinyatakan bahwa persepsi merupakan proses penginderaan stimulus yang diterima oleh individu melalui alat indera yang kemudian diinterpretasikan sehingga individu dapat memahami dan mengerti tentang stimulus yang diterimanya tersebut.

\section{RESELLER}

Menurut Keegan (2003) saluran distribusi adalah saluran yang digunakan oleh produsen untuk 
menyalurkan barang tersebut dari produsen sampai ke konsumen atau pemakai industri. Kotler (2003) mendefinisikan saluran distribusi adalah sekelompok perusahaan atau perseorangan yang memiliki hak pemilikan atas produk atau membantu memindahkan hak pemilikan produk atau jasa ketika akan dipindahkan dari produsen ke konsumen. Dalam kegiatan distribusi para anggota rantai nilai mengambil peran sebagai agen, pedagang besar, dan pengecer.

Fungsi utama saluran distribusi adalah menyalurkan barang dari produsen ke konsumen, maka perusahaan dalam melaksanakan dan menentukan saluran distribusi harus melakukan pertimbangan yang baik. Menurut Kotler (2003) distribusi menjalankan fungsi informasi, promosi, negosiasi, pemesanan, pembayaran, kepemilikan, dan berbagi resiko.

Di dunia bisnis online peran distribusi sebagai rantai nilai dimainkan oleh orang yang disebut dengan reseller dan/atau affiliate. Seperti halnya agen, reseller bisa dikatakan sebagai perwakilan penjualan yang memerankan fungsi-fungsi dalam distribusi. Baik agen, reseller, maupun affiliate memeroleh keuntungan dengan memperdagangkan produk orang lain dalam bentuk komisi dalam besaran tertentu atau prosentase tertentu.

Arti kata reseller adalah menjual kembali. Artinya aktivitas penjualan suatu produk yang dilakukan oleh seorang penjual setelah penjual tersebut membeli dari pihak lain. Pengertian yang keliru di masyarakat menganggap bahwa reseller adalah sebatas aktivitas promosi url web suatu produk dengan imbalan komisi dari setiap transaksi yang sebenarnya lebih tepat disebut affilate. Seorang reseller lebih cenderung untuk melakukan aktivitas penjualan. Sedang affiliate lebih mengambil peran promosi. Namun demikian seorang reseller dapat pula disebut sebagai affiliate, tetapi seorang affiliate belum tentu disebut seorang reseller.

Reseller seperti halnya agen sebagai perpanjangan tangan usaha pemilik produk memiliki sejumlah persyaratan yang ditetapkan oleh pemilik produk. Sebagai representasi perusahaan, prosedur standar harus dipenuhi untuk mengantisipasi terjadinya penyimpangan di luar ketentuan kerja yang sudah ditetapkan yang dapat menurunkan citra perusahaan atau pemilik produk.

Dibanding dengan reseller, affiliate lebih sederhana dalam hal persyaratan. Seorang affiliate tidak diwajibkan membeli produk terlebih dahulu sebelum dapat mempromosikannya kepada orang lain. Seorang affiliate dapat mendaftar secara gratis untuk memperoleh hak afiliasi dari sebuah produk. Pemilik produk atau pemilik usaha memandang penting keberadaan affiliate ini dalam membantu pengembangan promosi produknya dengan menawarkan besaran komisi/insentif yang menarik bila aktivitas afiliasinya terjadi transaksi atau pembelian. Biasanya pemilik produk mempertimbangkan pemilihan jenis model affiliasi ini untuk meluaskan daya jangkau kepada konsumen yang sebenarnya.

\section{METODE}

Penelitian ini menggunakan pendekatan kualitatif deskriptif. Untuk memperoleh pemahaman tentang persepsi reseller tentang keberadaan situs jejaring sosial digunakan metode diskusi kelompok fokus. Menurut Irwanto (1988) Focusing Group Discussion didefinisikan sebagai suatu proses pengumpulan informasi mengenai suatu permasalahan tertentu yang sangat spesifik melalui diskusi kelompok. Informan penelitian yang dalam hal ini para reseller diberi lembaran yang berisi tentang gambar aktivitas dalam outlet dan pertanyaan tentang situs jejaring sosial, dan kemudian memulai diskusi kelompok.

Pemilihan informan ditetapkan secara purposive yaitu para pemilik akun produk handphone dan pakaian dalam daftar pertemanan akun jejaring sosial peneliti. Peneliti menghubungi informan untuk berpartisipasi dalam diskusi kelompok fokus. Dari aktivitas ini diperoleh 12 orang yang bersedia dengan domisili di wilayah Malang dan dibagi ke dalam dua kelompok yaitu: kelompok 1: reseller produk handphone 7 peserta dan kelompok 2: reseller produk pakaian 5 peserta.

\section{HASIL}

Sebelum diskusi kelompok fokus membahas tentang peran jejaring sosial, peserta diminta memperhatikan gambar aktivitas sebuah outlet (toko) pada lembaran yang diberikan. Selanjutnya peserta diminta untuk menggambarkan secara verbal tentang gambar tersebut. Berikut komentar peserta:

Ini gambar sebuah toko yang di dalamnya ada orang berbelanja (6/handphone)

Ini suasana dalam toko yang dikunjungi orang untuk mencari barang kebutuhan (2/pakaian)

Orang yang sedang melihat-lihat barang di rak toko (3/pakaian)

Orang yang memilih produk dan membayar di kasir (1/handphone)

Pendapat yang pertama sebesar $50 \%$ atau sebanyak 6 orang menyatakan "aktivitas orang berbelanja 
di toko". Diskusi diantara 6 orang tersebut menjelaskan bahwa orang yang memasuki toko adalah orang yang memiliki niat untuk membeli sesuatu. Membeli menurut pendapat mereka adalah kegiatan membelanjakan uang untuk mendapatkan barang yang dibutuhkan. Pendapat kedua sebesar $17 \%$ atau sebanyak 2 orang menyatakan "orang yang mencari barang kebutuhan". Menurut mereka bahwa orang yang pergi dan masuk ke sebuah toko yakin bahwa apa yang dicari untuk dibeli ada di toko tersebut. Pendapat ketiga sebesar $25 \%$ atau sebanyak 3 orang menyatakan "melihat-lihat barang yang terpajang di rak toko". Menurut mereka orang yang masuk ke sebuah toko belum dapat dipastikan akan membeli. Dan pendapat keempat sebesar $8 \%$ atau sebanyak 1 orang menyatakan "memilih produk dan membayar di kasir". Menurutnya bahwa orang yang memasuki sebuah toko akan memilih-milih dan membandingkan produk kemudian membayar produk yang sesuai tersebut.

Diskusi dapat dibedakan dalam dua kategori yaitu pertama bahwa orang yang memasuki toko adalah orang yang memiliki niat untuk membeli kebutuhan. Sedang pemahaman pada kategori yang lain bahwa orang yang memasuki toko belum tentu akan membeli, karena dimungkinkan orang tersebut mencari alternatif pilihan untuk pemenuhan kebutuhannya.

Lembar berikutnya berisi tentang skema tentang jalur distribusi dengan berbagai tingkat mengacu kepada Kotler (2003), dan peserta diminta untuk menunjukkan berada di mana posisi mereka terhadap skema tersebut. Hal ini dimaksudkan untuk mendapatkan pemahaman tentang posisi reseller di dalam rantai nilai distribusi. Berikut komentar peserta:

"Saya termasuk pengecer kalau melihat skema ini (8/handphone-pakaian), Saya ini adalah agen produk (4/handph-one-pakaian)"

Peserta yang menyebut diri mereka pengecer berpandapat bahwa keberadaan mereka dalam rantai distribusi adalah orang yang berhubungan dengan pembeli akhir. Jumlah pembelian yang dilakukan oleh para pembeli mereka tidak lebih dari satu unit. Peserta yang menyatakan diri mereka sebagai agen berpendapat bahwa aktivitas mereka dalam rantai distribusi adalah orang yang membeli produk dari distributor utama dalam partai besar. Program dalam penjualan tidak terikat kepada distributor utama. Dalam penjualan mereka tidak terbatas pada penjualan eceran, seringkali mereka menjual dalam bentuk partai.

Berikutnya pertanyaan yang diajukan kepada peserta adalah apakah pertemanan di jejaring sosial selalu menghadirkan interaksi. Dari 12 peserta 10 diantaranya menjawab "ya", dan 2 lainnya menjawab "tidak". Berikut komentar peserta:

"Pertemanan di jejaring sosial yang sedang online memberikan comment terhadap status kita (10/handphone-pakaian). Orang yang mengomentari status kita belum tentu berinteraksi, bisa jadi sebatas iseng (2/handphone-pakaian)"

Pembahasan pada pertanyaan ini bertumpu pada pernyataan interaksi. Peserta yang menjawab "ya" berpendapat bahwa interaksi merupakan bentuk komunikasi dua arah. Tanpa melihat serius atau tidaknya isi dari komunikasi, setidaknya orang lain telah merespon apa yang disampaikan. Selain itu peserta yang menjawab "ya" menyatakan bahwa jejaring sosial cenderung lebih fun bila dibandingkan dengan blog atau bentuk situs lain. Sedang peserta yang menjawab "tidak" berpendapat bahwa interaksi merupakan komunikasi intens dan berisi hal yang penting. Di jejaring sosial orang hanya melakukan obrolan santai dan ringan.

Selanjutnya peserta menjawab pertanyaan tentang apakah setiap hal yang tercantum di jejaring sosial menjadi perhatian bagi orang lain. Dari 12 peserta 8 orang menyatakan "tidak" dan 4 orang menyatakan "ya". Berikut komentar peserta:

"Di jejaring sosial orang yang berkomunikasi cenderung untuk meng-clik profil teman obrolan dan melihat gambar yang di-upload. (4/handphonepakaian)

Orang hanya fokus memperhatikan status dan upload gambar kita saat itu, tanpa mengakses lebih dalam profil kita (8/handphone-pakaian)".

Peserta yang menjawab "tidak" menyebutkan bahwa orang yang terhubung di jejaring sosial hanya memperhatikan status dan atau gambar yang diunggah (upload) saat itu. Tidak serta merta pertemanan yang sedang online dan terhubung "saat itu" akan mengakses profil lebih jauh. Peserta yang menjawab "ya" menyebutkan bahwa pertemanan yang terhubung cenderung untuk mengakses profil lebih jauh. Hal tersebut terjadi karena unggahan selalu terkoneksi dengan profil.

Selanjutnya peserta membahas pada pertanyaan apakah akun jejaring sosial peserta seperti halnya dengan gambaran outlet yang ada pada lembar awal. 9 informan memberikan jawaban "ya" terhadap pertanyaan tersebut yang terdiri dari 5 reseller handphone dan 4 reseller pakaian. Berikut komentar peserta: 
"Karena daftar teman yang sedang berinteraksi dalam akun saya bertanya seputar tawaran saya dan meng-click foto produk yang ada di akun saya. (pakaian). Karena orang yang melakukan obrolan dengan saya melihat foto-foto produk yang saya up-load dan bertanya seputar produk tersebut (handphone).

Peserta yang memberikan jawaban "ya" memandang bahwa pertemanan yang berinteraksi di jejaring sosial dan bertanya seputar produk atau perannya seperti aktivitas di dalam toko offline. Demikian halnya dengan pertemanan yang melakukan click pada gambar produk yang terpampang di profil akun jejaring sosial dipandang sebagai orang yang memilih-milih produk pada rak pajangan di toko.

Sedangkan 3 peserta yang memberikan jawaban "tidak" terhadap pertanyaan tersebut yang terdiri dari 2 reseller handphone dan 1 orang reseller pakaian. Berikut komentar peserta:

Akun jejaring sosial tidak sampai membuat terjadinya transaksi bagi produk yang saya tawarkan (handphone/pakaian)

Peserta yang memberikan jawaban "tidak" berpendapat bahwa aktivitas di dalam toko mendekati terjadinya transaksi. Artinya orang yang melihat-lihat pada sebuah ruang pajang (display) cenderung untuk membeli produk tersebut. Sedang di jejaring sosial, orang yang meng-click foto produk yang ditawarkan seringkali sebatas melihat-lihat.

Selanjutnya peserta diberi pertanyaan aktivitas yang dilakukan melalui jejaring sosial. Dari 12 peserta 4 di antaranya baik dari reseller handphone maupun pakaian menyebutkan tentang keseharian yang di alami. 3 peserta menyebutkan membahas informasi terkini dan sesekali dikaitkan dengan produk mereka. 3 peserta berikutnya menyebutkan topik tertentu dan dikaitkan dengan produk. Dan 2 peserta lainnya menyebutkan melakukan penawaran dan mendorong teman bicara membaginya dengan orang lain. Berikut komentar peserta:

"Di jejaring sosial saya lebih senang masuk ke obrolan, membicarakan aktivitas apa yang sedang dilakukan (4/handphone-pakaian).

Saya lebih senang meng-upload singkat berita terbaru kemudian menunggu respon dari pertemanan. Selanjutnya saling berbalas komentar, dan bila bisa dihubungkan dengan produk saya maka sekali waktu saya hubung-hubungkan (3/handphone-pakaian)

Saya sering mengangkat cerita singkat, tips-tips, atau peribahasa yang nantiya saya kaitkan dengan produk saya, sehingga responnya rame (3/handphone-pakaian)
Saya lebih senang meng-upload gambar produk, kemudian men-share di pertemanan (2/handphonepakaian)"

Pernyataan yang diberikan oleh peserta seputar aktivitas di jejaring sosial dapat dikelompokkan menjadi dua yaitu kelompok yang menggunakan jejaring sosial hanya sebagai media sosialisasi, dan di kelompok lain yang menggunakan jejaring sosial sebagai media pendukung informasi produk yang dimiliki.

Berikutnya peserta diminta memperhatikan lembar yang berisi gambar sebuah katalog produk. Kemudian peserta diminta memberikan gambaran secara verbal dari gambar tersebut. Berikut komentar peserta:

"Ini gambar katalog yang isinya foto produk dan penjelasan produk. Selain itu ada nama produsen, alamatnya, dan telpon yang bisa dihubungi (12/ handphone-pakaian)"

Penjelasan yang diberikan oleh seluruh peserta tidak ada perbedaan. Peserta menganggap bahwa katalog produk berfungsi sebagai media bagi perusahaan untuk memberikan penjelasan secara lengkap dari sebuah produk. Dari

Selanjutnya pertanyaan yang diberikan kepada peserta diskusi adalah peran reseller dan jejaring sosial sangat erat hubungannya. Dari 12 peserta 5 peserta menjawab "erat" dan 7 peserta menjawab "tidak". Berikut komentar peserta:

"Jejaring sosial itu sebagai media pendukung untuk menginformasikan produk dan alamat outlet saya (rumah-counter) yang selama ini berfungsi sebagai display. Saya sering mengajak mereka yang tertarik dengan produk saya untuk datang ke tempat saya. Jadi perannya seperti alat promosi (7/handphone-pakaian)

Akun jejaring sosial saya sangat menunjang pada penjualan produk yang saya tawarkan. Informasi produk saya bisa dibaca oleh jaringan pertemanan saya. Disamping itu seringkali getok tular dari konsumen saya kepada orang lain untuk mengunjungi akun saya. (5/handphone-pakaian)"

Peserta yang menyatakan "tidak" bukan berarti menolak eratnya hubungan peran reseller dan jejaring sosial. Mereka beranggapan bahwa situs jejaring sosial memiliki peran sebagai media informasi bagi produk seperti halnya katalog. Dan peserta yang menjawab "ya" menjelaskan bahwa aktivitas penjualan yang dilakukan mengalami perkembangan dengan keberadaan situs jejaring sosial yang mereka miliki.

Dari paparan di atas dapat dijelaskan bahwa peran situs jejaring sosial dalam persepsi reseller 
sebagai media informasi dan interaksi dalam aktivitas bisnis. Dari komentar peserta diperoleh penjelasan bahwa situs jejaring sosial memiliki peran informasi kepada jaringan pertemanan. Hal ini seperti temuan Kautsarina (2013) yang menyatakan bahwa aplikasi jejaring sosial adalah sebagai sarana memperkenalkan produk kepada daftar pertemanan. Lebih lanjut hasil diskusi menjelaskan bahwa peran informasi ini dapat memberikan dampak getok tular yang dalam konsep pemasaran disebut word of mouth.

Selain peran informasi, dari hasil diskusi diperoleh penjelasan peran situs jejaring sosial sebagai media interaktif. Aktivitas menulis status yang kemudian menarik minat pertemanan memberikan komentar dapat menggiring pertemanan kepada sebuah perbincangan. Perbincangan tersebut memberikan kesempatan bagi reseller untuk menarik perbincangan kepada produk yang ditawarkan. Peran interaktif ini sejalan dengan temuan Manuel (2013) meski dalam konteks yang lebih luas. Hasil penelitian menyatakan bahwa internet menciptakan peluang interaksi potensial dengan konsumen atau pelanggan pada skala global yang berdampak pada kinerja perusahaan.

\section{KESIMPULAN}

Situs jejaring sosial merupakan sarana berbasiskan internet yang berfungsi sebagai media komunikasi untuk melakukan promosi, negosiasi, dan transaksi.
Dari paparan diskusi kelompok fokus diperoleh penjelasan bahwa situs jejaring sosial merupakan sarana menginformasikan tawaran, perkembangan tawaran, dan peran sebagai reseller. Peran situs jejaring sosial adalah sebagai media untuk menyampaikan informasi, melakukan interaksi, dan transaksi.

\section{DAFTAR RUJUKAN}

2012. Upright Decesion. www.marketing.co.id. Diakses Agustus 2014.

Engel, B., Miniard. 1995. Perilaku Konsumen. Jakarta: Penerbit Erlangga.

Irwanto. 1998. Focus Group Discussion. Pusat Kajian Pembangunan Masyarakat.

Kautsarina. 2013. Pemasaran Elektronika melalui Aplikasi Jejajring Sosial. Jurnal Studi Komunikasi dan Media. Vol 17 No. 2.

Kotler, P. 2003. Manajemen Pemasaran. Prentice Hall, Inc.

Marketing Science Vol 33 no.2 p.122-138. www.emeral dinsight.com diakses Agustus 2014.

Manuel, Y. 2013. Inovasi dan Dampak Jasa Iklan Berbasis Elektronika. Jurnal JIBEKA. Vol 7.

Rayport and Jaworski. 2001. e-commerce. NewYork: McGraw-Hill.

Schacter, D. 2011. Psychology. Worth Publishers. www. wikipedia.co.id. Diakses 2014.

Sukma, A.A. 2012. Analisis Faktor-faktor yang Mempengaruhi Keputusan Pembelian melalui Social Networking Websites. Jurnal Ekonomi Manajemen. 